\title{
ABBREVIATIONS, CITATIONS, TRANSLATIONS, AND TRANSLITERATIONS
}

GP

$H D$

$\mathrm{MnT}$

MT

$P h M$

$S E$

ShM

$S P$

P, N

$\mathrm{Pq}, \mathrm{Nq}$

Ps, Ns

$M$

$T$

JT

BT
The Guide of the Perplexed

Hilkhot De'ot

Moshe ibn Tibbon's translation of ShM (the base text in Heller's and Frankel's editions)

Mishneh Torah

Perush ha-Mishnayot

"Short Enumeration of the Commandments"

(Minyan ha Qatsar)

Sefer ha-Mitsvot

Shemonah Peraqim

Positive, Negative commandment, according to Maimonides Positive, Negative commandment, according to Qayyara Positive, Negative commandment, according to Sa'adiah

Mishnah

Tosefta

Jerusalem (Palestinian) Talmud

Babylonian Talmud 